\title{
Financial performance of Hungarian and Romanian retail food small businesses
}

\author{
Veronika Fenyves \\ University of Debrecen, Debrecen, Hungary \\ Kinga Emese Zsido and Ioan Bircea \\ Department of Economics and Law, \\ University of Medicine, Pharmacy, Sciences and Technology, \\ George Emil Palade of Targu Mures, Targu Mures, Romania, and \\ Tibor Tarnoczi \\ University of Debrecen, Debrecen, Hungary
}

Retail food small businesses

Received 10 May 2019 Revised 29 August 2019 29 October 2019

Accepted 9 December 2019

\begin{abstract}
Purpose - Changes in food retailing (globalization, concentration) have negative impacts on smaller, "traditional" food retail businesses. Their market share decreasing year by year. The purpose of this study is to examine and compare the financial performances of these businesses under the given circumstances and current economic environment in a Hungarian and a Romanian county.

Design/methodology/approach - The study is based on two complete databases, including all companies that behoove retail food activity (considering the NACE cod) in the counties of Hajdu-Bihar (Hungary) and Cluj (Romania). The database analyzed contains the financial statements for five consecutive years for 212 and 690 businesses. Databases were examined by the most typical financial indicators using the multivariate and univariate analysis of variance and the k-medoid cluster analysis methods.

Findings - The results of the analysis have shown that there are differences in the number of retail food companies in the case of two counties, both in number and in financial performance. Companies in Hajdú-Bihar county perform better in terms of financial ratios than those in Cluj county. The groups created by k-medoids cluster analysis are relatively well distinguished in the case of Hajdú-Bihar county, while the picture is much more mixed in the case of Kolozs county. However, it is also important to note that the companies analyzed should generally perform better to survive.

Research limitations/implications - Among the limitations of the study, it is important to note that the findings are relevant only to the two counties examined. Another limiting factor is that quite several companies had to be excluded from the analysis due to missing data or outliers.

Practical implications - The study presents for the corporate decision-makers the current performance of the companies of the sector examined in the two counties. The results of the study highlight the business areas of concern in management. The findings show that they need to change this performance to strengthen their market position. We believe that it is not enough to complain about the expansion of the supermarket chains, but they should take appropriate actions to improve their situation. Based on the results of the study, it can be concluded that there is a need to improve the financial efficiency of retail food companies in both counties to survive in the long run. This improvement is essential because retailers can play an important role in smaller settlements and narrower residential environments.

Originality/value - Comparative analysis of retail food companies in similar counties in these two neighboring countries has not been conducted using complex financial analysis. The study revealed the common and/or individual characteristics of these companies.
\end{abstract}

Keywords Financial performance, Analysis of variance, K-medoids clustering, Food retail

Paper type Research paper

\section{JEL Classification - F10}

(C) Veronika Fenyves, Kinga Emese Zsido, Ioan Bircea and Tibor Tarnoczi. Published by Emerald Publishing Limited. This article is published under the Creative Commons Attribution (CC BY 4.0) licence. Anyone may reproduce, distribute, translate and create derivative works of this article (for both commercial and non-commercial purposes), subject to full attribution to the original publication and authors. The full terms of this licence may be seen at http://creativecommons.org/licences/by/4.0/legalcode

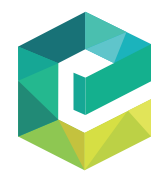

British Food Journal Vol. 122 No. 11, 2020 pp. $3451-3471$ Emerald Publishing Limited DOI 10.1108/BFJ-05-2019-0330 
BFJ

122,11

3452

\section{Introduction}

In the past decades, the characteristics of economic life changed significantly across Europe. The events and processes that occurred have led to radical changes, and their effects can also already be felt today, and their future impacts will be probably even stronger too: as a result of the regime changes, the economies became more open for privatization processes and to inflows the foreign capitals. The state-owned companies and cooperatives have undergone transformations or became bankrupt or came to buying up, and many new businesses have established (Fenyves, 2016). The European Union assures the free flow of capital, information, human resources, products, etc. at this moment, facilitating the spread of globalization (Györe et al., 2009) and the growth of concentration. These phenomena have varying degrees, but they are present in all industries, including commerce (McCullough et al., 2008). Eastern Europe has become a new opportunity, a new market for European retailers (Myers and Alexander, 1997). The extent of globalization is also illustrated by statistical data; for example, German and French trading companies produce nearly 40 percent of their sales on foreign markets (Deloitte, 2016). The international retailers have been looking for new market opportunities as a result of the saturation of the internal markets, and in many cases, to enter the markets of developing countries have required less effort (Agárdi et al., 2017).

Nevertheless, globalization does not necessarily and directly imply positive financial performance. In the literature, several researchers have studied the impact of participation in international markets on business performance. Researchers found out that expansion in the region, in the case of geographically and culturally closed countries, has a positive impact on business performance (the well-established business models do not require major changes in these counties), whereas markets require greater adaptations and higher cost levels in the case of farther and characteristically different countries (Agárdi et al., 2017; Hitt et al., 2006; Sohl, 2012; Oh et al., 2015).

Investigating further the commercial activity, the results of the analysis per product categories highlight the importance of food retailing. In the food retail, supermarkets have an increasing market share ( 80 percent in some western European countries, while this level is lower in Central and Eastern Europe, e.g. about 70 percent in Hungary and around 60 percent in Romania), to play down the traditional convenience stores and create them a more difficult situation. In recent years, consumers have favored hyper- and supermarkets, discount stores and various store chains. There is a tendency to drop the number of grocery stores drastically, while the average size of shops in square meters is growing (Fenyves, 2016). According to the European Commission (2014), discount stores have experienced the strongest growth in number of outlets and floorspace over the past decade: they have increased their sales areas by 81 percent between 2000 and 2011 across the EU, whereas the total sales areas of hypermarkets increased by 46 percent and that of supermarkets by 26 percent between 2000 and 2011 (European Commission, 2014).

Various statistical data undoubtedly emphasize the importance and weight of commercial activity for both countries. Examining the number of enterprises in the two countries, the proportion of enterprises engaged in commercial activities is the highest in Romania 32.16 percent (2017) as well as in Hungary 22.54 percent (2017). The number and proportion of businesses operating in the trade and vehicle repair sector significantly exceed any other activity. Also, the importance of this activity is underlined by the contribution to the gross value added, both in Hungary and in Romania. In 2016, in Hungary (same as in Romania), the contribution of trade and vehicle repair to the gross value added was 10.1 percent, and this sector is the strongest after the manufacturing industry. In terms of the number of employees in Romania, 15.87 percent (2016) of the employees work in trade, while in Hungary, this figure is close to 12.00 percent (2016).

The main goal of the research is a comparative analysis of the financial performance of all retail food businesses, which operate in given regions (Cluj and Hajdú-Bihar counties) of two 
Central and Eastern European countries, namely, Romania and Hungary. For the evaluation of financial performance, we used the data for several years of the financial statements of Hungarian and Romanian companies. Using multivariate and simple analysis of variance, we compared the profitability ratios of the two counties. Companies in the counties are grouped with their profitability ratios using k-medoids clustering. We then examine the significant differences between clusters using the financial variables chosen.

\section{Literature review}

The food commerce market in Europe has been increasing since 1990, especially in Middle and Eastern Europe. For European retailer companies, the Middle and Eastern European countries provided new opportunities, and they provide them in our days too, although there are some risks regarding political and economic uncertainties (Myers and Alexander, 1997). Figure 1 presents the income of the biggest retailers in the Czech Republic, Poland, Hungary, Slovakia and Romania (Zsido, 2018).

Comparing the turnover of the biggest retailers of Czech Republic, Poland, Hungary, Slovakia and Romania, we can notice that Kaufland (CZ, RO), Tesco (CZ, PL, HU), Lidl (CZ, PL, HU, RO), Penny Market (CZ, HU, RO), Auchan (HU, RO) are in the top10 in several countries (Table I). "These multinational companies play a crucial role" in countries' food retail market. The phenomenon of globalization is unquestionable (Zsido, 2018).

According to a European Commission study (European Commission, 2014), the European Union member states can be classified into three categories, based on their modern retail market shares:

(1) over 65 percent of the total food market: the current retail market had already developed before 2000 and has maintained this high modern retail market share (Germany, Finland, the UK, Sweden, France, Luxembourg and Austria);

(2) states where modern retail has developed since 2000, and it is higher in 2001 than in 2000 (The Netherlands, Estonia, Belgium, Ireland, Spain, Portugal, Hungary and Slovakia);

(3) less than 50 percent of the total food market: modern retail has developed significantly but remains relatively low compared to other member states (Latvia, Poland, Cyprus, Bulgaria and Romania).

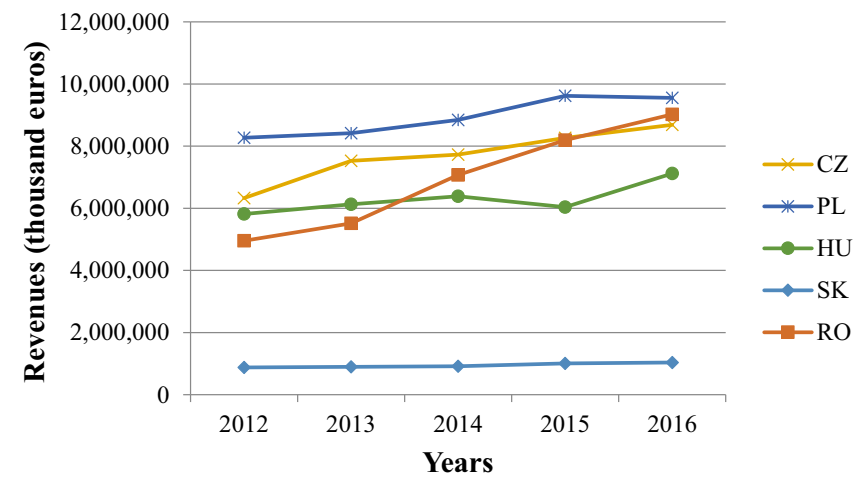

Source: Zsido (2018)
Retail food small businesses

3453
Figure 1. Total food and foodrelated retail turnovers of top10 enterprises in 2012-2016 (thousand euros) 


\begin{tabular}{|c|c|c|c|c|c|c|}
\hline & & & & & & \\
\hline${ }_{12 \%}^{B F J}$ & & $\mathrm{CZ}$ & PL & $\mathrm{HU}$ & SK & $\mathrm{RO}$ \\
\hline & 1 & $\begin{array}{l}\text { Kaufland } \\
\text { Ceska Rep. }\end{array}$ & Eurocash S.A. & $\begin{array}{l}\text { TESCO-GLOBAL } \\
\text { Zrt. }\end{array}$ & Labas s.r.o. & $\begin{array}{l}\text { Kaufland Ro. } \\
\text { SCS }\end{array}$ \\
\hline & 2 & $\begin{array}{l}\text { Tesco stores } \\
\text { CR a.s. }\end{array}$ & Tesco (Polska) & $\begin{array}{l}\text { SPAR Magyarország } \\
\text { Ker.Kft. }\end{array}$ & CBA Slovakia, a.s. & Carrefour Ro. SA \\
\hline & 3 & Lidl Ceska Rep. & $\begin{array}{l}\text { Zabka Polska } \\
\text { S.A. }\end{array}$ & AUCHAN & Milk-agro, spol. s r.o. & $\begin{array}{l}\text { Lidl Discount } \\
\text { SRL }\end{array}$ \\
\hline & 4 & Penny market & Piotr I Pawel & Lidl Magyarország & Coop Jednota Nove & Auchan Ro. SA \\
\hline & 5 & $\begin{array}{l}\text { s.r.o. } \\
\text { Globus CR k.s. }\end{array}$ & $\begin{array}{l}\text { S.A. } \\
\text { Ledi Sp. z o.o. }\end{array}$ & $\begin{array}{l}\text { Ker. Bt. } \\
\text { Penny-market Ker. } \\
\text { Kft. }\end{array}$ & $\begin{array}{l}\text { Zamky } \\
\text { COOP Jednota } \\
\text { Krupina }\end{array}$ & Mega image SRL \\
\hline & 6 & Billa spol. s.r.o. & Lidl Polska & METRO Ker. Kft. & $\begin{array}{l}\text { Velkoobchodny } \\
\text { druzstevny }\end{array}$ & $\begin{array}{l}\text { Profi Rom food } \\
\text { SRL }\end{array}$ \\
\hline & 7 & $\begin{array}{l}\text { Coop } \\
\text { Centrum Dr }\end{array}$ & Tabak Polska & $\begin{array}{l}\text { ALDI Elelmiszer } \\
\text { Ker. Bt. }\end{array}$ & COOP Jednota Cadca & Rewe (Ro.) SRL \\
\hline & 8 & $\begin{array}{l}\text { Coop } \\
\text { Morava s.r.o. }\end{array}$ & Greek trade & $\begin{array}{l}\text { UNIO COOP Szov. } \\
\text { Ker. Zrt. }\end{array}$ & COOP Jednota Zilina & $\begin{array}{l}\text { Ro. Hypermarche } \\
\text { SA }\end{array}$ \\
\hline & 9 & $\begin{array}{l}\text { Jednota } \\
\text { Spotrebni Dr. }\end{array}$ & Spoldzielcza & $\begin{array}{l}\text { COOP Szolnok } \\
\text { Ker. Zrt. }\end{array}$ & COOP Jednota Nitra & $\begin{array}{l}\text { Columbus Op. } \\
\text { SRL }\end{array}$ \\
\hline & 10 & Lama plus & Cukiernia & Krupp es Tarsa & COOP Jednota & Artima SA \\
\hline od retail & & s.r.o. & Sowa & Ker. Kft. & Galanta & \\
\hline & & rce: Zsido (2018) & & & & \\
\hline
\end{tabular}

The changing demands of consumers also determine the changes in food trade. Changes in household composition, the aging population, demands healthier products and increased environmental awareness have had an impact on the grocery retail market in Europe (European Commission, 2014). Along with the income increase, the technology and lifestyle changes, the consumer's preferences are changing: they are looking for safer, more healthful products and also, it is essential the process of food production (Newman and Cullen, 2001; Codron et al., 2005). Rudawska and Bilinska-Reformat (2018) associate the changes in retail formats to new technologies, environmental factors, increasing customers' demands and with the development of modern grocery retailing, such as hypermarkets, supermarkets and discount shops.

Once modern retailers enter Middle and Eastern European countries, a clear trend concerning greater retailers' concentration has been observed in the 2004-2012 period (European Commission, 2014). This concentration process is also demonstrated by Zsido (2018) using the Lorenz curve for five states in 2016: in the case of four countries (Czech Republic, Poland, Hungary and Romania), the concentration is very high. However, the food and food-related retail companies in Slovakia have a smaller concentration (here, globalization has not reached such a level as much as in other countries). In Hungary, as well as is Romania, there are a few retailers who dominate the whole market; their income and market share are increasing (Figures 2 and 3).

The question arises as to what effect these changes and tendencies have on "traditional," smaller-sized food retail units. There is much literature dealing with the super- and hypermarkets financial situation, neglecting the financial situation of traditional convenience stores. In this paper, we analyzed the financial performance of food retail small businesses from two Eastern European countries (Hungary and Romania). In literature, the concept of performance is presented as the goals achieving, value creation, effectiveness, efficiency, economy, productivity and so on. (Aguinis, 2013; Armstrong, 2015; Armstrong and Taylor, 2014; Chirila, 2004; Bircea, 2016; Böcskei and Fekete, 2012; Dobrin et al., 2012; Miles, 2012; Neely et al., 1995; Nábrádi and Petö, 2009; Rappaport, 1998; Ristea, 2003; Szucs and Farkasné, 


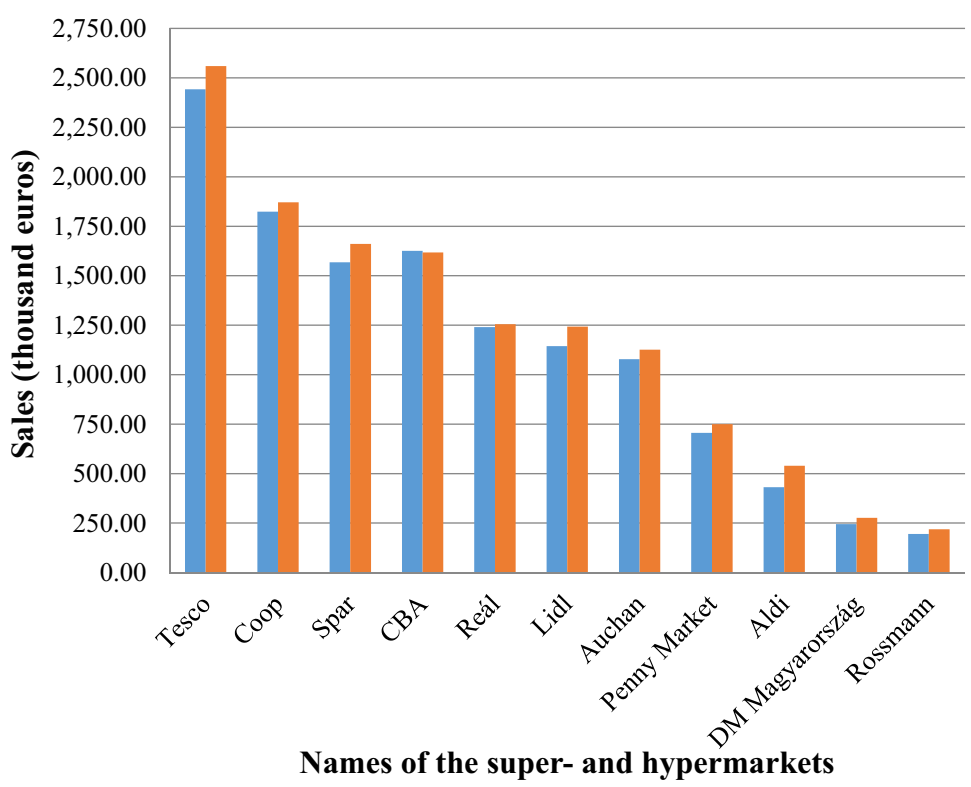

Retail food small businesses

Source: own editing, based on own calculations

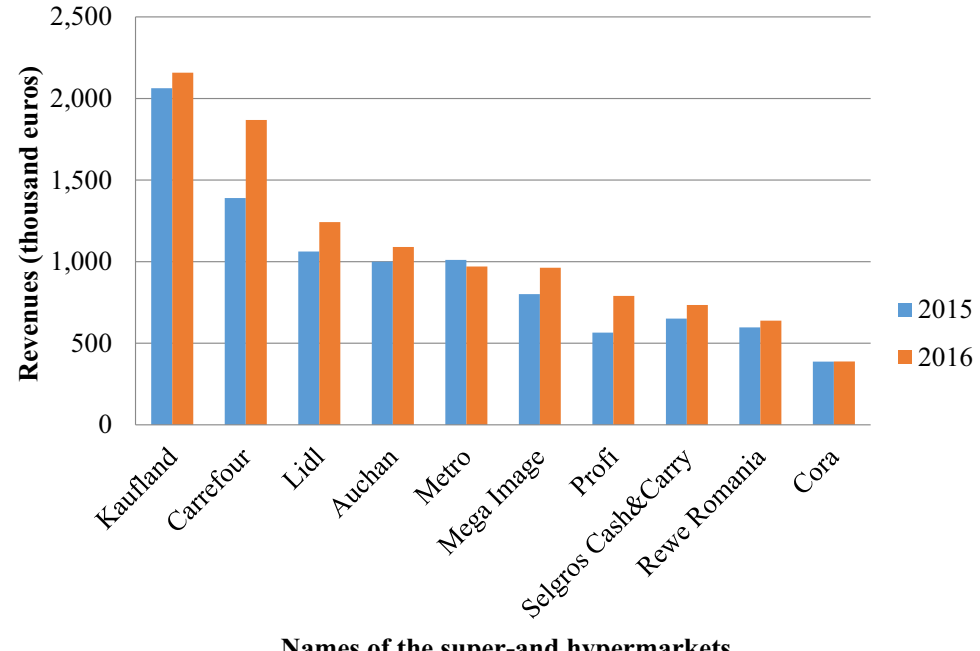

Source: Zsido, 2018

Figure 3. Sales values in Romanian super- and hypermarkets for 2015-2016 (thousand euros)

2008; Tangen, 2005; Wimmer, 2000). All of these economic characteristics can be defined using relative indicators, based on the financial statements of companies. Note that some other studies apply a different approach and identify the term "performance" with the appraised company value (Takacs, 2014) or with the value of the company's brands (Takacs, 2015); however, the current research does not use such approaches. 
$\mathrm{BFJ}$

122,11

3456

Hernant et al. (2007) k-means cluster analysis was used to compare Swedish supermarkets. They used different financial ratios for comparison. Based on the analysis performed, they concluded that stores working under different competitive conditions possess different critical success factors, and they should manage on a different basis.

The analysis was started with the analysis of the composition of assets and their financing sources. The efficiency of asset use can significantly influence the profitability of the company. Therefore, it is essential to calculate different ratios about the enterprise's assets for the analysis of economic activities (Birher et al., 2006). The composition of the assets can also allude to a firm's stability, flexibility or even specific activity (Musinszki, 2013). The ratios connected to inventories and their changes are very important in the case of the asset composition of commercial enterprises. Inventory (stock) management has a significant impact on the enterprises, as it can greatly influence the size of the capital invested in inventories, financial position of the company, costs associated with stockpiling, material supply and profitability of the business (Birher et al., 2006). The analysis of the composition of financing brings into focus the ratio of equity and debts, capital tension (ratio the liabilities to the equity), the level of indebtedness.

During the analysis, the financial situation of companies has a crucial role. It is essential to monitor and assess the company's financial stability, liquidity and ability of the company to meet its obligations (Fenyves and Zsidó, 2014; Musinszki, 2013). Liquidity problems can easily cause malfunctions that may even lead to insolvency situations. In analyzing the financial situation, the liquidity can examine using the current ratio and quick ratio indicators.

Among the indicators of the income situation, the most commonly used indicators are the following: ROS (return on sales), ROA (return on assets) and ROE (return on equity) (Musinszki, 2013). These three indicators can uniquely combine business goals. ROS gives an insight into the cost management as well as the cost and price politics of the business. ROA shows the efficiency of assets management, which is especially important for commercial activity and the ROE ratio for own invested resources. In our view, the ratio of material expenses to the net sales revenue plays an essential role in the analysis. Material costs, which can be easily measured, can affect the profitability of sold products (Musinszki, 2014). The next profitability ratio examined compares the operating profit to net sales revenue. The most important efficiency indicator for trading activities is the inventory turnover ratio. Knowing the inventory turnover ratio is essential for inventory management; its value shows how many times the average inventory was transformed into money in the period investigated (Birher et al., 2006).

\section{Data and methodologies}

\subsection{Database}

The data was collected from financial statements of companies from Hajdú-Bihar (Hungary) and Cluj county (Romania). The companies were examined, which are classified into food retail store $(4,711)$ sector based on the NACE code. The two databases contain the financial statements of all the enterprises of the given county, which are operated in the field mentioned above of activity, thus ensuring the completeness of the analysis.

We also considered several aspects of selecting the two territorial units (counties). The first criterion was that the selected territorial units are not in the capital of countries (usually the headquarters of the big hyper-and supermarkets are in the capitals, and because the aim of the research is "the analysis of the business performance of traditional, smaller food retail units," the capitals were excluded from the analysis). On the other hand, the territorial units examined were supposed to have a researchable size, to make a full analysis, and the analyzed counties are neither the largest nor the smallest county in the given country considering the proportions. Social, economic and developmental levels of the counties had to be similar. 
The enterprises of Hajdú-Bihar county were chosen from the OPTEN database, according to the scope of activities and the headquarters. The statements of operating companies were downloaded from the Electronic Reporting Portal (e-beszamolo.kim.gov.hu). In Hajdú-Bihar county, 246 enterprises were suited to the specified conditions. The database also includes micro-, small- and medium-sized companies. In the case of Cluj county, the database was provided by the Tax Office of Cluj county. 1,020 companies met the conditions in Romania.

Of the available companies, those that did not have financial statements every investigated year, those that had zero sales or inventories values and those that had outlier values considering their profitability ratios were omitted. Outliers were filtered out using the boxplot diagram of the $\mathrm{R}$ statistical program. The number of companies used in the analysis was 190 firms in Hajdú-Bihar county and 648 firms in Cluj county.

\subsection{Statistical analysis}

The statistical analysis of databases and the editing of the graphs were performed using Microsoft Excel and SPSS software. The analysis of the databases was started by calculating the basic statistical characteristics (mean, median, standard deviation, minimum, maximum, skew, kurtosis) of the variables used in the analysis. The results of basic statistical analysis confirmed our assumption that the analyzed companies are inhomogeneous, and the differences among them are significant.

Multivariate and univariate analysis of variance (MANOVA and ANOVA) were used to compare counties based on the profitability ratios. The multivariate ANOVA extends the ANOVA by taking into consideration multiple dependent variables and bundles them together into a weighted linear combination or composite variable. The multivariate analysis of variance extends the ANOVA by taking into consideration multiple dependent variables and close up them together into a weighted linear combination or a composite variable. For MANOVA, we used the Pillai test to test for a statistically significant difference. The Pillai test is suitable to test the equality of covariance matrices of two $p$-variate normal distributions with unknown mean vectors.

Nowadays, we are working with ever larger and more complex databases, and as a result, the data and information that we need to process and analyze are also very diverse and comprehensive (heterogeneous). Large databases must be classified or rather be divided into homogeneous groups. The essence of grouping is to create groups with small distances between elements and large distances between groups. Using homogeneous groups during the analysis, we can interpret better the results of the research, and finally, the results provide a clearer picture to conclude.

A variety of techniques and methods are available to create homogeneous clusters, such as partitioning methods (k-means, k-medoids), hierarchical methods (agglomerative approach, divisive clustering), density-based methods (DBSCAN algorithm), grid-based methods (CLIQUE algorithm). Well-known and commonly used methods are k-means and kmedoids methods (Soni and Patel, 2017). For larger samples, the interpretation of hierarchical cluster analysis is considerably more difficult, so it is preferable to apply non-hierarchical (kmeans, k-medoids) methods in such a situation (Sajtos and Mitev, 2007).

The k-means clustering method groups the data based on the group means (centroids). Initially, the cluster means are calculated by the random selection of the data. This method is sensitive to outliers, because the object with very large values may substantially influence the group means. The k-medoids method uses representative objects as reference points instead of taking the mean value of the objects in each cluster (Velmurugan and Santhanam, 2010). The k-medoids method groups the data according to the distance between the elements and groups.

The k-medoids and k-means methods were used by Arora et al. (2016), and as a result, they affirm that the execution time is better for the k-medoids method than the k-means method,
Retail food small businesses 
BFJ

122,11

3458

and the k-medoids method is nonsensitive to outliers. Contrary to these results, Velmurugan (2012), compared also k-medoids and k-means clustering algorithms, and their results showed that the k-means algorithm provided better results than the k-medoids algorithm. Sandhya and Surya (2015) comparing k-means and k-medoids methods in the case of heterogeneous populations, they stated that k-medoids outperform the k-means application. The k-medoids method based on the distance between the individuals of the database results in more relevant groups than the k-means process, taking into account the average values of the groups. Park and Jun (2009) also studied the differences between the two methods, and they performed studies about sensitivity to extreme values. They showed that the k-means process is much more sensitive to outliers than the k-medoids method. Gandhi and Srivastava (2014) also preferred the k-medoid algorithm in terms of the cluster quality and the elapsed time.

The k-medoids clustering method was chosen in the study because, in our opinion, the $\mathrm{k}$ medoids cluster analysis can provide a more balanced grouping because it uses a selected element of the database as a central element, while the k-means clustering method uses a calculated element, i.e. the mean. The k-medoids method groups the entities of the population by comparing the distance between the data points (Tompa, 2017). As a grouping criteria, we set the essential profitability ratios: ROS, ROA and ROE. These three ratios together give an insight into cost management, efficiency asset management and the combination of financing resources, which play an essential role in the rationalization process of activities.

The enterprises with zero net sales revenue were removed from the analysis because they had not sales in that period. In the next step, we identified the outliers of the profitability ratios using boxplot diagrams that can distort the results, and they have also removed from the analysis. The optimal cluster number was determined by gap statistics. The gap statistic method compares the total value within the cluster variation for different values of $\mathrm{k}$ with their central values. The optimal cluster number will be a value that maximizes the gap statistic which means that the clustering structure is far from a random uniform distribution of points (Tibshirani et al., 2001). Finally, based on the gap statistic, five clusters were chosen in the case of the Hungarian database, while in the case of the Romanian database, 10 clusters.

As the purpose of the analysis was to investigate the financial performance of the companies, only relative ratios were used for the analysis. Literature resources also support this idea, because professionals identify this concept of business performance with efficiency and profitability (Neely et al., 1995; Rappaport, 1998). It follows that the determination of efficiency is possible using relative indicators (Table II).

\section{Research results}

\subsection{Comparison of the profitability ratios of the two counties}

In this study, we aimed to compare the performance of the two counties regarding retail food companies. We think that the ultimate test of corporate performance is the profit they make, and their best representations are the profitability ratios. With this in mind, the study first compares the key profitability ratios (ROS, ROA, ROE) of the two counties (Figures 4-6).

Figure 4 clearly shows that there is a significant difference between the ROS of the two counties. The average ratio value in Cluj county is negative in every year, and there are several times higher than in Hajdú-Bihar county. The figure also presents that the confidence intervals calculated by the $t$-test for both counties were the highest in 2015 .

The trends for ROA are similar to those for ROS (Figure 5). However, the differences between ROA ratios of the two counties are even more significant. The figure also presents that high confidence intervals for ROA have been falling for different years. High values in Cluj county may also indicate that asset management efficiency is better there than in HajdúBihar county (ROA $=$ ROS $*$ total assets turnover). 
Assets and financing sources

Financial situation

Profitability situation

Source: own editing
Composition of assets (\%):

Fixed assets share (Fixed assets/Total assets * 100)

businesses

Inventory share (Inventories/Total assets * 100)

Composition of financing sources (\%):

Equity proportion (Equity/(Equity and Liabilities) * 100)

Indebtedness ratio (Debt/Sources * 100)

Proportion of short-term liabilities (Short-term liabilities/Total liabilities * 100)

Liquidity:

Current ratio $=$ Current assets/Short term liabilities

Quick ratio $=($ Current assets - inventories $) /$ Short-term liabilities

Profitability ratios (\%):

Material expenses/Net sales * 100

Operating profit/Net sales * 100

ROS $=$ Return on sales (Profit after tax/Net sales * 100)

$\mathrm{ROE}=$ Return on equity (Profit after tax/Equity $* 100$ )

ROA $=$ Return on assets (Profit after tax/Total assets $* 100$ )

Inventory turnover ratio (Net sales/Inventories)

Table II.

Indicators selected for financial performance analysis
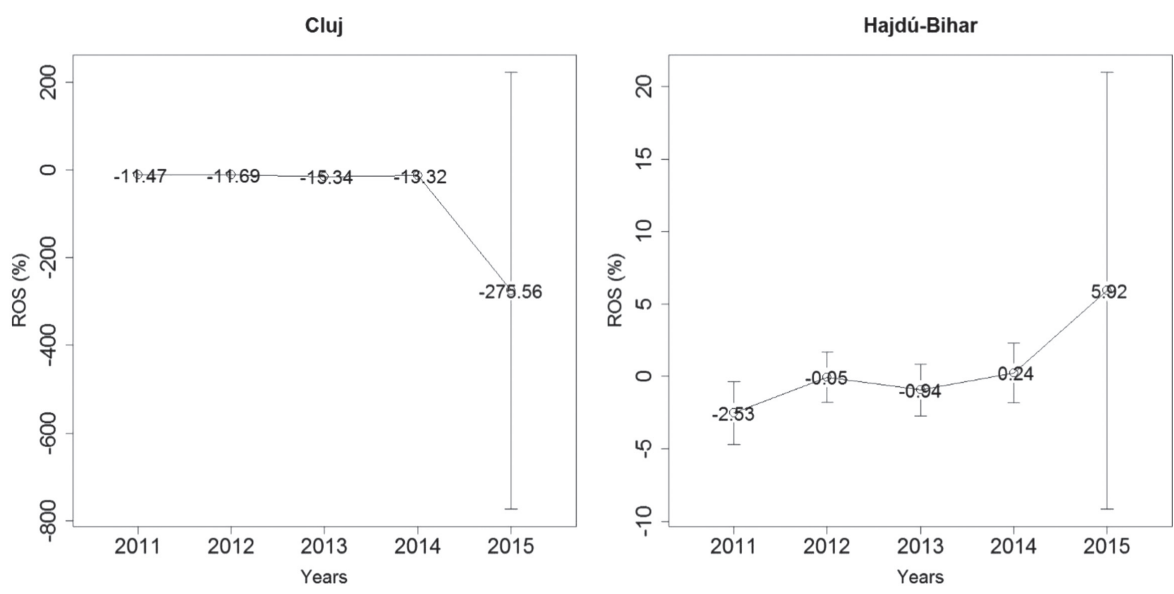

Source: drawn by R statistical system

Figure 4.

Changes in average ROS ratio values for retail food companies in the two counties in the years analyzed

The ROE values show an increase relative to ROA in one year and a decrease in another (Figure 6). The average change is higher for Hungarian companies than for Romanian companies, which may be because Hungarian food retail companies are more indebted than Romanian ones $(\mathrm{ROE}=\mathrm{ROA} *(1+$ Debt to equity ratio)).

In the case of the Romanian county, high negative equity values may occur more often because, in Romania, there is no regulation about the negative value of equity, while in Hungary, there are specific requirements for this. Table III shows the number and proportion of companies with negative equity. From Table III, we can see that more than twice as many businesses have negative equity in Cluj county as in Hajdú-Bihar county. Therefore, the different accounting regulations in force in the two countries can also influence the differences in the profitability ratios of the two counties. 
$\mathrm{BFJ}$

122,11

Figure 5.

Changes in average ROA ratio values for retail food companies in the two counties in the years analyzed

Figure 6.

Changes in average ROA ratio values for retail food companies in the two counties in the years analyzed
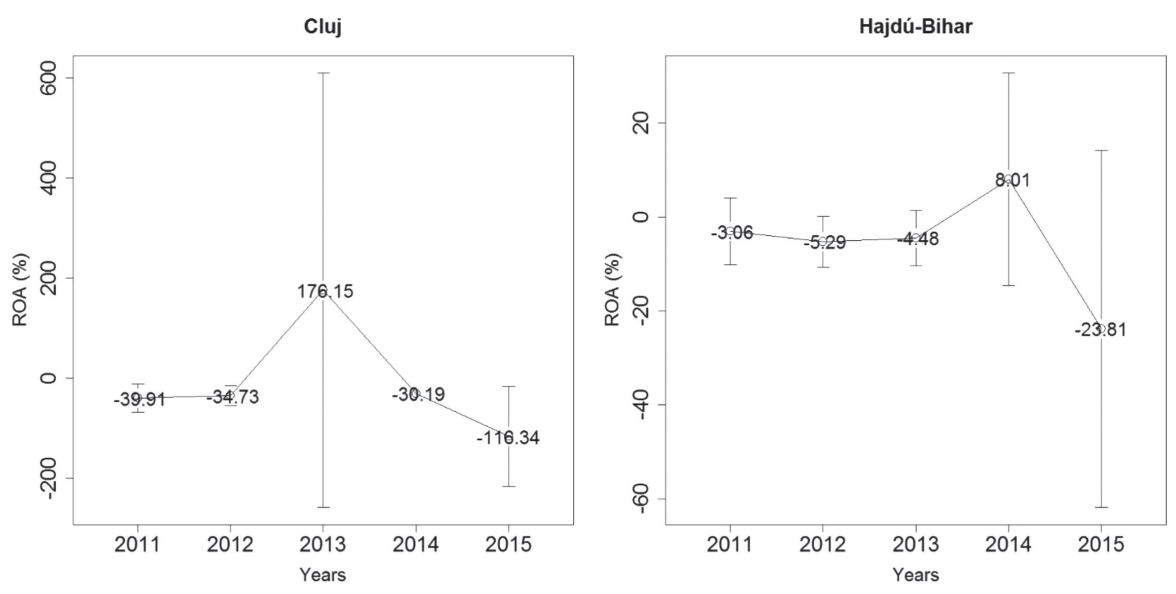

Source: drawn by R statistical system
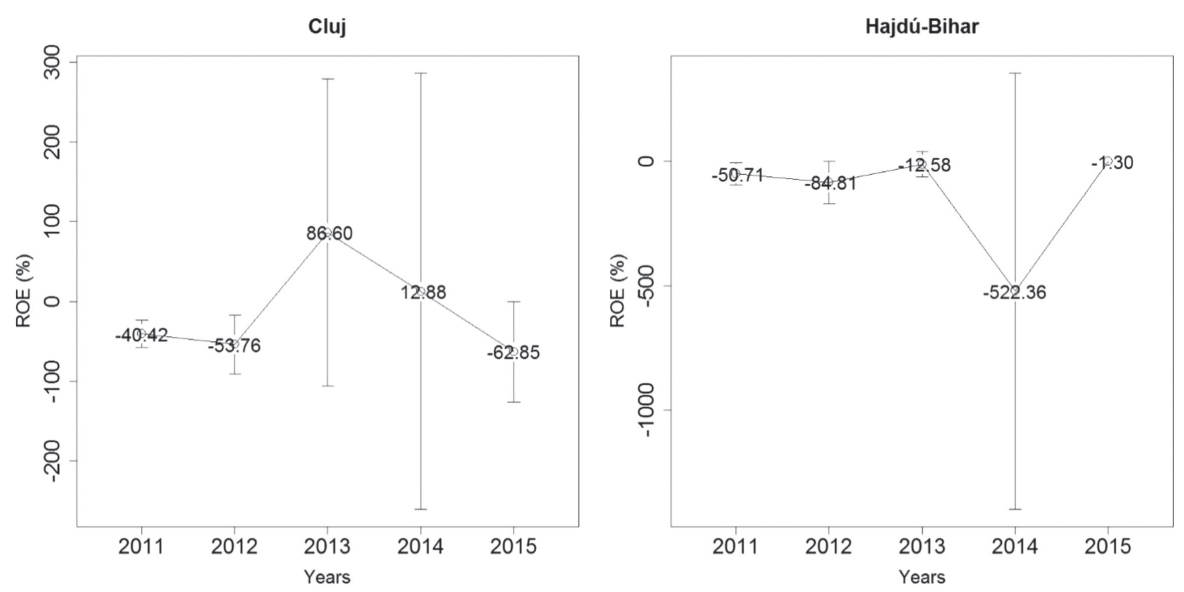

Source: drawn by R statistical system

In summary, the profitability of retail food businesses in Hajdú-Bihar county is better than that of Cluj county. The figures (Figures 4-6) also show that the dispersion of the ratio values of the retail food businesses of Cluj county is higher than that of the Hajdú-Bihar counties. The latter indicates that businesses in Cluj county are likely to have a higher risk.

Figures 4-6 also show that there are extreme values that can significantly influence the analysis. Therefore, it is expedient to omit these values from the analysis.

There is no significant difference between the two counties analyzed, examining the average of the three profitability indicators.

Table IV shows the result of the analysis of variance. If the probability value in the table is not more than 5 percent, then we accept the null hypothesis that the examined factors differ statistically significantly from each other; otherwise, we reject it. It can be 
seen from the table that according to the three ratios examined (ROS, ROA, ROE), the companies of the two counties are statistically significantly different in three years (2011, 2012, 2014), and there are no statistically significant differences in two years $(2013,2015)$. Based on the ROS ratio, the two counties differ statistically significantly in three years $(2011,2012,2013)$. Taking into account the ROA indicator, there is a statistically significant difference between the two counties only in one year (2014). According to the ROE indicator, there is no statistically significant difference between the two counties.

\subsection{General description of business performance analysis results}

Due to the large dispersion of data, the average of the whole population does not adequately represent it. Consequently, we decided to divide the whole population into groups and used kmedoids cluster analysis for classification. The clusters were calculated based on five-year averages of financial ratios of both counties.

For both counties, two types of tables were made from the results of the calculations. The first type of tables (Tables V and VI) contain the results of the k-medoids cluster analysis, the averages of the selected financial ratios of clusters and the significance levels of the analysis of variance for each ratio. The other type of tables (Tables VII and VIII) contain averages of clusters calculated from the basic accounting data.

First, multivariate analysis of variance was performed for companies in both counties, using the so-called Pillai test. With the Pillai test in the case of cluster analysis, we can examine whether clusters differ from each other, considering all of the selected financial ratios. If the Pillai test shows a significant difference, we can continue the analysis with pairwise comparison using a simple analysis of variance.

Two colors evaluated the extreme ratio values of clusters with the favorable (dark green) and unfavorable (dark red), and the other values on a color scale between the extreme colors.

\begin{tabular}{lcccc}
\hline & \multicolumn{2}{c}{ Cluj county } & \multicolumn{2}{c}{ Hajdú-Bihar county } \\
Years & $\begin{array}{c}\text { Number of } \\
\text { companies }\end{array}$ & $\begin{array}{c}\text { Proportion of } \\
\text { companies }\end{array}$ & $\begin{array}{c}\text { Number of } \\
\text { companies }\end{array}$ & $\begin{array}{c}\text { Proportion of } \\
\text { companies }\end{array}$ \\
\hline 2011 & 399 & $57.83 \%$ & 48 & $22.75 \%$ \\
2012 & 401 & $58.12 \%$ & 47 & $22.27 \%$ \\
2013 & 408 & $59.13 \%$ & 52 & $24.64 \%$ \\
2014 & 402 & $58.26 \%$ & 49 & $23.22 \%$ \\
2015 & 398 & $57.68 \%$ & 45 & $21.33 \%$ \\
Total number of & 690 & $100.00 \%$ & 211 & $100.00 \%$ \\
companies analyzed & & & &
\end{tabular}

Source: own calculation
Retail food small businesses

3461
Table III.

The number and proportion of companies with negative equity in Cluj county and Hajdú-

Bihar county

\begin{tabular}{|c|c|c|c|c|c|}
\hline Indicators & 2011 & 2012 & $\begin{array}{l}\text { Years } \\
2013\end{array}$ & 2014 & 2015 \\
\hline Pillai-test & $3.27 \%$ & $4.30 \%$ & $44.56 \%$ & $0.19 \%$ & $47.80 \%$ \\
\hline ROS & $0.81 \%$ & $1.86 \%$ & $14.66 \%$ & $1.61 \%$ & $53.96 \%$ \\
\hline $\mathrm{ROA}$ & $16.08 \%$ & $11.29 \%$ & $65.17 \%$ & $0.37 \%$ & $31.82 \%$ \\
\hline ROE & $61.19 \%$ & $45.44 \%$ & $57.73 \%$ & $12.81 \%$ & $29.04 \%$ \\
\hline
\end{tabular}

Source: own calculation 
BFJ 122,11

Table V.

Average ratio values of company clusters in Hajdú-Bihar county. (A color version of this table is available online)

\begin{tabular}{|c|c|c|c|c|c|c|}
\hline Clusters & 1 & 2 & 3 & 4 & 5 & \multirow{4}{*}{$\begin{array}{l}\text { Significance } \\
\text { levels of } \\
\text { pairwise } \\
\text { comparisons } \\
(\%)\end{array}$} \\
\hline Number of companies & 35 & 39 & 38 & 48 & 30 & \\
\hline $\begin{array}{l}\text { Proportion of companies in } \\
\text { clusters }\end{array}$ & $18.4 \%$ & $20.5 \%$ & $20.0 \%$ & $25.3 \%$ & $15.8 \%$ & \\
\hline Ratios & \multicolumn{5}{|c|}{ Five-year averages of ratios } & \\
\hline $\operatorname{ROS}(\%)$ & 1.08 & 0.56 & -3.12 & -0.69 & 4.23 & 15.32 \\
\hline ROA (\%) & 2.19 & 1.65 & -7.42 & -1.59 & 11.47 & 7.08 \\
\hline ROE (\%) & 6.56 & 9.02 & 2.12 & 0.58 & 31.75 & 1.69 \\
\hline Fixed assets share (\%) & 64.79 & 39.09 & 2.50 & 17.87 & 7.35 & 0.00 \\
\hline Inventory share $(\%)$ & 20.66 & 35.20 & 66.00 & 48.25 & 48.89 & 0.00 \\
\hline Equity proportion (\%) & 33.29 & 12.39 & -28.05 & 15.25 & 32.16 & 86.24 \\
\hline Indebtedness ratio $(\%)$ & 59.73 & 78.51 & 113.40 & 79.77 & 66.90 & 62.82 \\
\hline $\begin{array}{l}\text { Proportion of short-term } \\
\text { liabilities (\%) }\end{array}$ & 80.74 & 88.55 & 81.34 & 86.76 & 89.70 & 21.77 \\
\hline Current ratio & 2.46 & 1.88 & 4.41 & 2.77 & 5.09 & 8.00 \\
\hline Quick ratio & 0.41 & 0.41 & 0.32 & 0.41 & 0.47 & 43.89 \\
\hline $\begin{array}{l}\text { Material expenses/Net sales } \\
(\%)\end{array}$ & 77.84 & 80.46 & 86.03 & 84.86 & 76.81 & 72.45 \\
\hline Operating profit/Net sales (\%) & 1.74 & 1.01 & -2.90 & -0.52 & 6.10 & 10.37 \\
\hline $\begin{array}{l}\text { Inventory turnover ratio } \\
\text { (turnover/year) }\end{array}$ & 13.91 & 20.73 & 8.57 & 12.79 & 24.86 & 54.53 \\
\hline
\end{tabular}

Source: own editing based on own calculations

\begin{tabular}{lcrrrr}
\hline Clusters & 1 & 2 & 3 & \multicolumn{1}{c}{} & \multicolumn{1}{c}{5} \\
Number of companies & 35 & 39 & 38 & 48 & \multicolumn{1}{c}{30} \\
\hline Total assets & 151,341 & 167,475 & 17,045 & 32,366 & 13,215 \\
Fixed assets & 98,088 & 71,244 & 588 & 8,130 & 1,304 \\
Current assets & 50,061 & 93,081 & 16,362 & 23,829 & 11,727 \\
Short-term liabilities & 53,233 & 60,489 & 9,821 & 14,640 & 7,490 \\
Long-term liabilities & 15,460 & 8,120 & 2,699 & 1,846 & 787 \\
Equity & 74,458 & 83,154 & 3,387 & 15,000 & 4,682 \\
Total revenue & 352,150 & 437,456 & 48,901 & 92,883 & 81,465 \\
Operating profit & 5,258 & 10,950 & -407 & 493 & 2,031 \\
After-tax profit & 4,067 & 10,534 & -447 & 330 & 1,741 \\
Source: own editing based on own calculations & & & & \\
\hline
\end{tabular}

We did not classify the ratios of the asset proportion (the ratio of fixed assets and inventories) and the ratio of short-term liability proportion as favorable or unfavorable indicators because there is not precise classification for good or bad values. It is important to note that dark green color only means that the financial ratio for a particular cluster is best compared to other clusters. However, the value of the ratio is possibly below the expected ratio value.

Table VI.

Average accounting values of company clusters in Hajdú-Bihar 


\begin{tabular}{|c|c|c|c|c|c|c|c|c|c|c|c|}
\hline Clusters & 1 & 2 & 3 & 4 & 5 & 6 & 7 & 8 & 9 & 10 & \multirow{4}{*}{$\begin{array}{c}\text { Significance } \\
\text { levels of } \\
\text { pairwise } \\
\text { comparisons } \\
(\%)\end{array}$} \\
\hline Number of companies & 63 & 42 & 75 & 61 & 131 & 68 & 47 & 39 & 54 & 68 & \\
\hline $\begin{array}{l}\text { Proportion of } \\
\text { companies in clusters }\end{array}$ & $9.7 \%$ & $6.5 \%$ & $11.6 \%$ & $9.4 \%$ & $20.2 \%$ & $10.5 \%$ & $7.3 \%$ & $6.0 \%$ & $8.3 \%$ & $10.5 \%$ & \\
\hline Ratios & \multicolumn{10}{|c|}{ Five-year averages of ratios } & \\
\hline $\operatorname{ROS}(\%)$ & -8.68 & 4.46 & 1.86 & -3.61 & 1.17 & -11.24 & -48.75 & -29.77 & 0.33 & 12.67 & 8.07 \\
\hline ROA (\%) & -13.33 & 9.31 & 5.17 & -8.52 & 1.17 & -40.80 & -29.97 & -114.64 & 1.02 & 16.85 & 0.00 \\
\hline $\operatorname{ROE}(\%)$ & 20.34 & -52.33 & 22.25 & 8.12 & 0.39 & 25.01 & 19.06 & 24.00 & 85.37 & 23.26 & 0.00 \\
\hline Fixed assets share (\%) & 17.58 & 20.76 & 17.96 & 13.99 & 29.31 & 12.82 & 27.37 & 14.56 & 18.66 & 18.87 & 74.82 \\
\hline Inventory share (\%) & 66.47 & 59.44 & 60.20 & 68.42 & 52.51 & 69.92 & 59.03 & 65.55 & 63.90 & 37.75 & 0.26 \\
\hline Equity proportion (\%) & -78.44 & -22.36 & 27.75 & -126.86 & 2.71 & -229.46 & -154.58 & -553.01 & 0.97 & 41.39 & 0.57 \\
\hline Indebtedness ratio (\%) & 178.18 & 122.22 & 72.18 & 226.71 & 97.13 & 329.41 & 254.14 & 653.00 & 97.83 & 58.36 & 0.60 \\
\hline $\begin{array}{l}\text { Proportion of short- } \\
\text { term liabilities }(\%)\end{array}$ & 72.00 & 82.59 & 80.35 & 68.37 & 80.62 & 72.96 & 65.60 & 78.52 & 79.23 & 89.17 & 12.85 \\
\hline Current ratio & 2.52 & 1.97 & 2.03 & 2.39 & 1.94 & 1.27 & 2.08 & 0.43 & 1.74 & 7.79 & 0.38 \\
\hline Quick ratio & 0.20 & 0.28 & 0.26 & 0.20 & 0.29 & 0.20 & 0.23 & 0.33 & 0.24 & 0.56 & 0.00 \\
\hline $\begin{array}{l}\text { Material expenses/Net } \\
\text { sales }(\%)\end{array}$ & 87.40 & 77.51 & 83.17 & 84.55 & 80.44 & 86.78 & 93.77 & 88.79 & 80.62 & 69.06 & 2.03 \\
\hline $\begin{array}{l}\text { Operating profit/Net } \\
\text { sales (\%) }\end{array}$ & -7.08 & 6.39 & 2.55 & -2.35 & 2.38 & -10.02 & -43.38 & -28.41 & 1.71 & 14.41 & 13.3 \\
\hline $\begin{array}{l}\text { Inventory turnover } \\
\text { ratio (turnover/year) }\end{array}$ & 15.04 & 33.52 & 10.77 & 6.90 & 39.57 & 11.23 & 3.97 & 12.01 & 10.09 & 66.13 & 43.4 \\
\hline
\end{tabular}

Retail food small businesses

3463

Table VII.

Average ratio values of enterprise clusters in Cluj county. (A color version of this table is available online)

\subsection{Business performance of retail food businesses in Hungary}

The analysis of the Hungarian companies was performed with five clusters (Table V). The Pillai test showed a significant difference in the case of Haldú-Bihar county, where the significance level was less than 0.1 percent. It means that the five clusters sign a significant difference from each other, considering the selected ratios. Because the Pillai test signed a significant difference among the clusters, pairwise analyses of variance were made. We can see from Table $V$ there are only three (ROE, fixed assets share, inventory share) ratios, which are significantly different on 5 percent of the significance level. Besides, there are two ratios (ROA, current ratio), which are significantly different on 10 percent of the significance level. The results indicate that these variables are which cause significant differences between the individual clusters.

Based on the values in Table $\mathrm{V}$, we can conclude that the most favorable results (mostly dark green values) are for Cluster 5 (15.80 percent of the population). This cluster, taking into account Table VI, contains smaller companies with the lowest average assets and relatively low revenue, while they manage their business most efficiency. They have the highest average ROS and ROA ratios. If we ranked the resulting clusters according to the color scale, we would get the following order: $5,1,2,3$, 4 . Cluster 3 (20.00 percent of the population) has the worst results, and almost all of the ratios shown have a dark red color. It can be seen that the average profit values of Cluster 3 are negatives, and the average efficiency of the companies in this cluster is also low overall, considering the values of Table VI. Table VI also shows that companies in Cluster 3 have the lowest average fixed assets, less than half of the second smallest one (Cluster 5). They also have very low average revenues. It can also be seen from 
BFJ
122,11

\section{4}

\begin{tabular}{|c|c|}
\hline$\stackrel{\infty}{\longrightarrow} \infty$ & 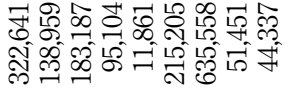 \\
\hline の & 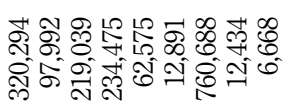 \\
\hline$\infty$ கి & 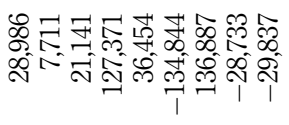 \\
\hline & 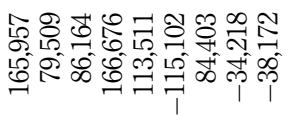 \\
\hline $0 \%$ & 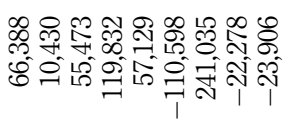 \\
\hline L & 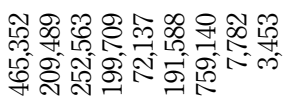 \\
\hline+6 & 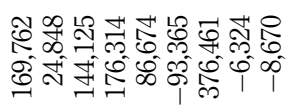 \\
\hline & 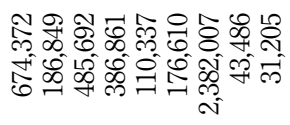 \\
\hline$\sim \mathcal{F}$ & 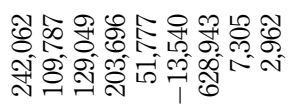 \\
\hline- & 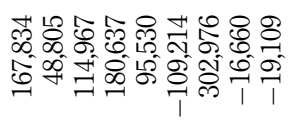 \\
\hline 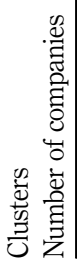 & 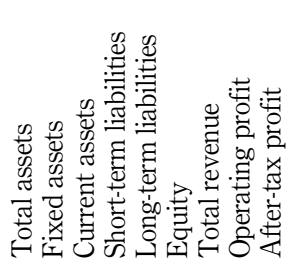 \\
\hline
\end{tabular}

Table VIII.

Average accounting values of company clusters in Cluj county 
Table $\mathrm{V}$ that the quick ratio is very low for each cluster, indicating that the stocks are relatively high in the companies.

It can be stated that the average performance of Clusters 5, 1,2 is good or acceptable, while the average performance of Clusters 3,4 is low or bad, taking into account Tables V and VI. It can also be stated that better firms hardly represent a higher proportion (54.7 percent) in the whole population than the worse firms (45.3 percent).

Based on the analysis of variance, $\mathrm{ROE}$, fixed assets share and inventory share ratios play a decisive role in cluster differences, while ROA and current ratio play a significant role. Table V also shows that the bad firms (Clusters 3 and 4) have higher indebtedness, but are not considered to be low in the case of better firms.

\subsection{Business performance of retail food businesses in Romania}

For the Romanian database, we divided the companies included in the analysis into 10 clusters (Tables VII and VIII). The Pillai test showed a significant difference in the case of Cluj county, where the significance level was less than 0.1 percent. It means that the five clusters sign a significant difference from each other, considering the selected ratios. Because the Pillai test signed a significant difference among the clusters, there were made the pairwise analyses of variance. We can see from Table $V$ there are eight (ROA, ROE, inventory share, equity proportion, indebtedness, current ratio, quick ratio, material expenses/net sales) ratios, which are significantly different on 5 percent of the significance level. Also, there is one ratio (ROS) that is significantly different on 10 percent of the significance level. The results indicate that these variables are which cause significant differences between the individual clusters.

Cluj county's best performing companies are in Cluster 10 (10.5 percent), where only one yellow color is among the dark greens (Table VII). Firms in Cluster 10 belong to larger companies (Table VIII). Table VII shows that Cluj county companies have very extreme values for equity proportion and indebtedness ratios. These values can be most likely related to those shown in Table III. There is not a regulation for negative equity in Romania. We can see in Table VIII that the following clusters have negative average equities: 1, 2, 4, 6, 7, 8 . These six clusters account for 49.38 percent of the total population that is nearly half part of them.

It is much more difficult to establish a definite order in the case of clusters of companies in Cluj county. Unambiguously, only the first location of Cluster 10 can be identified. Based on the data in Tables VII and VIII, the following order can be created: 10, 3, 5, 2, 9, 4, 1, 6, 7, 8 .

It can be stated that the performance of the companies of the Cluster 10 (10.5 percent) is considered excellent, the performance of the companies of Cluster 3 (11.6 percent) can be considered good, Clusters 2, 5 and 9 (35.0 percent) are still acceptable (Table VII). This means that less than half of companies (47.1 percent) deliver at least acceptable performance in Cluj county. The performance of smaller companies is less satisfactory in Cluj county.

\subsection{Comparing the financial performance of retail food companies in Hajdú-Bihar and Cluj county \\ Comparison of variance analysis results of the two counties:}

(1) According to the Pillai test, the clusters of both counties differ statistically significantly.

(2) In the case of Hajdú-Bihar county companies, only three indicators have a statistically significant effect on cluster differences, while in the case of Cluj county companies, eight indicators. There are only two financial indicators that can be found for both counties: ROE and inventory share ratios. 
BFJ

122,11

\section{6}

As a result of the financial performance analysis of the two counties food retail companies, I would highlight the following results:

(1) In the composition of the assets of enterprises, long-term investments are on a low level. Looking at the annual values, the proportion of fixed assets in Hajdú-Bihar county ranges from 20 to 30 percent (average is 26.13 percent), in Cluj county, somewhat lower, this ratio is between 10 and 30 percent (average is 20.12 percent).

(2) The inventory share ratio of the Hungarian companies is at a lower level than in the case of the Romanian firms: the Hungarian five-year average is 44.14 percent and the Romanian is 59.19 percent. The level of inventory can depend on the turnover ratio. There is enough big difference in turnover ratios: the average inventory turnover ratio at the Hungarian enterprises is 15.69 turnovers/year, and 23.50 turnovers/year for Romanian companies. The difference between the two counties is 1.5 times.

(3) Looking at the ratios of equity and liabilities, we perceived a more significant difference between the two databases. In terms of capital strength, the Hungarian enterprises show a more stable situation, unlike the Romanian companies, where 50.62 percent of the whole population has positive values. This very high level of negative capital strength is primarily the result of the negative after-tax profit (annual accumulation). Zsidó and Stefanescu (2017) showed a more optimistic vision and a positive trend in the development of the after-tax profit of Romanian companies. They state that after the economic crisis in 2010, the number of Romanian companies with positive results is increasing year by year (49.31 percent of retail food businesses in Cluj county had positive results in 2011 and 67.54 percent by 2015).

(4) The capital strength is closely linked to the indebtedness ratio: there are only a few Romanian companies (33 percent of the whole population), where the level of liabilities is good or at an acceptable level. Indebtedness poses a high risk, even more, if it is coupled with low profitability.

(5) Regarding the current ratio, we mostly see good results for both counties: the Hungarian companies have good average ratios (between 1.88 and 5.09); there are only minor problems for the Romanian companies, but they have also good ratios (between 0.43 and 7.79). However, the average quick ratio is no longer as good as the current ratio: between 0.32 and 0.47 in Hajdú-Bihar county and between 0.20 and 0.56 in Cluj county. These values are far below the expected value of 1 .

(6) Comparing the ROS and ROA ratios, we can conclude that 41 percent of the Hungarian enterprises and 61 percent of the Romanian enterprises have negative ratios in the case of these profitability ratios. The situation is different for the ROE indicator, where the number of companies with a negative indicator decreased: 29 percent of the Hungarian and 18 percent of the Romanian firms. The decrease is due to negative equity values, which result in negative equity multipliers, and the negative ROAs multiplied by the negative equity multipliers give a positive ROE. For Romanian companies, the decline was greater because of the higher proportion of firms with negative equity multipliers.

We classify the companies of the two counties according to their financial performance into the following groups:

(1) good (all the three profitability ratios are at least +5 percent, good capital strength and liquidity); in this category, Hungarian enterprises stand out. There are more Hungarian companies rated with a good result than Romanian ones (only 20 percent of the Romanian companies can be evaluated with good performance); 


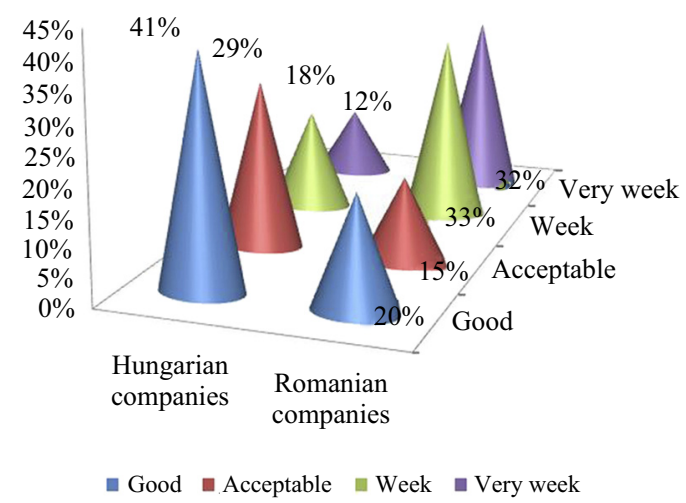

Source: own editing based on own calculations
Retail food small businesses

3467

Figure 7.

Financial performance of the Hungarian and Romanian companies

(2) acceptable (profitability indicators are positive, capital strength acceptable, normal liquidity values); even in this case, the proportion of Hungarian enterprises (29 percent) far exceeds the proportion of Romanian enterprises (15 percent);

(3) weak profitability ratios (profitability ratios near-zero value, operating profit/revenue is positive) were for 18 percent of the Hungarian enterprises and 33 percent of the Romanian enterprises;

(4) very weak results (all three profitability ratios are well below zero), we can characterize 12 percent of the Hungarian enterprises and 32 percent of the Romanian enterprises (Figure 7).

\section{Conclusions, suggestions}

The number of food retail units is higher in Cluj county than in Hajdú-Bihar county, which can already be determined from the initial database. The one reason for this is that in Hungary, there are already shops of different supermarket chains in smaller towns too.

Based on the analysis of financial ratios, it can be concluded on the whole that there are significant differences between the two counties. If we calculate the negative and positive profitability ratios separately, we get the following average values for ROS, ROA and ROE: Hajdú-Bihar county $-6.3,-21.04$ and -42.22 percent, respectively; Cluj county -16.18 , -46.62 and -1873.15 percent respectively, for negative values; Hajdú-Bihar county 3.80, 9.00 and 31.00 percent, respectively; Cluj county 5.88, 10.16 and 64.95 percent, respectively, for positive values. However, the previous figures do not give a true picture of the ROE because of what has already been described above. It can be stated that the negative values are much higher in Cluj county, and that the negative values have a higher proportion in this county. Based on this, it can be stated that the profitability of retail food companies in Hajdú-Bihar county is slightly better than that of Cluj county.

It can also be stated that the average indebtedness of the companies of Cluj county is much higher than that of the Hajdú-Bihar county (Cluj: 181.15 percent and Hajdú-Bihar: 80.51 percent). The average overall liquidity (based on current ratio) situation is also worse in Cluj county (2.49) than in Hajdú-Bihar county (3.22), but both ratios exceed the expected value. In the case of the average quick ratio, the situation is bad in both counties, but the figures in Cluj county (0.28) are lower than in Hajdú-Bihar county (0.40).

With the help of the k-medoids cluster analysis, the retail food companies of Hajdú-Bihar county could be grouped much more clearly than the companies of Cluj county. Except for 
BFJ

122,11

3468

three clusters $(3,5,9)$, companies in Cluj county have a much more mixed picture than those in Hajdú-Bihar. The variance analysis performed for the clusters showed a statistically significant difference between the two clusters.

To reduce the differences between the clusters, the ROE, ratio of fixed assets and ratio of current assets should be given more attention in Hajdú-Bihar county. The last two metrics can be handled together because the change of fixed assets has a definite impact on the current assets. To reduce the cluster difference, eight financial ratios for Romanian firms are shown in Table VII.

Based on the results obtained, it can be concluded that there is a need to improve the financial efficiency of retail food companies in both counties to survive in the long run.

In our opinion, the lack of investment resources (seen at the low level of tangible assets) and the low profit margins (resulting in low ROS, ROA and ROE values) are hindering business development. However, the higher profit margin cannot be a real option for smaller companies where hyper- and supermarkets operate because they charge low prices.

Peculiarities and current trends of the retail food markets taking into account the development, no conclusions can widely be drawn from the financial performance of the five business years studied. However, these results may highlight areas where problems exist, and companies need to pay more attention to these areas to survive. Better performance in the next period may give them a better chance to survive.

Of course, "traditional" retail stores and companies are currently in a difficult situation, but there is no risk there where these companies will disappear from the market where the people have no other options. We can also be sure that there will be stores that can handle the smaller needs of a particular area (shops in residential areas, 24/7 shops).

In this situation, we think that companies need to focus on realizing well-founded economic and financial analysis that provides useful information for management in preparing their decision-making. The introduction of management control activities can contribute to long-term survival and sustainable development (Zéman et al., 2018).

Concerning a large number of negative equity values of the Romanian companies, we propose to prepare a regulation on the protection of equity. This regulation should oblige the owners to perform various provisions to make an end of this situation within a given period. Such regulation can improve the financial performance of businesses, lead to greater carefulness and more prudent decision-making.

\section{References}

Agárdi, I., Berezvai, Z. and Alt, M.A. (2017), "Relationship between international diversification, innovation and performance in European food trade", Economic Review, Vol. LXIV, pp. 805-822, doi: 10.18414/KSZ.2017.7-8.805.

Aguinis, H. (2013), Performance Management, 3rd ed., Pearson Prentice Hall, Upper Saddle River, NJ.

Armstrong, M. (2015), Armstrong's Handbook of Performance Management: An Evidence Based Guide to Delivering High Performance, 5th ed., London Kogan Page, New Delhi.

Armstrong, M. and Taylor, S. (2014), Armstrong's Handbook of Human Resource Management Practice, 13th ed., Kogan Page Publishers, ISBN 10 0749469641, ISBN 13 978-0749469641.

Arora, P., Deepali, D. and Varshney, S. (2016), “Analysis of K-means and K-medoids algorithm for big data, International Conference on Information Security \& Privacy (ICISP2015), 11-12 December 2015, Nagpur, India", Procedia Computer Science, Vol. 78 No. 2016, pp. 507-512.

Bircea, I. (2016), Financial Analysis, Applications and Problems, Cluj University Press, Babes-Bolyai University, ISBN 978-606-37-0086-6, p. 65.

Birher, I., Pucsek, J., Sándor, L. and Sztanó, I. (2006), Economic Analysis of Business Activity, Perfekt Publisher, Budapest. 
Böcskei, E. and Fekete, H. (2012), "Measuring corporate performance over the past decade - the role of performance management", Controller, Vol. 8 No. 2012/1, pp. 1-5.

Chirila, E. (2004), "Defining and measuring enterprise performance", The Annals of the University of Oradea, Economic Sciences, Vol. XIII No. 2004, pp. 151-155.

Retail food small businesses

Codron, J.M., Grunert, K., Giraud-Heraud, E., Soler, L.G. and Regmi, A. (2005), "New directions in global food markets, retail sector responses to changing consumer preferences, chapter 3", Economic Research Service, Agriculture Information Bulletin, No. 794, pp. 32-46.

Deloitte (2016), Global Powers of Retailing 2016 Navigation the New Digital Divide, Deloitte, London.

Dobrin, C.O., Popescu, G.N., Popescu, V.A. and Popescu, C.R. (2012), "The concept of performance in business organizations - case study on the employee performance in Romanian business organizations", Proceedings of the 6th International Management Conference "Approaches in Organisational Management”, 15-16 November 2012, Bucharest, Romania.

European Commission (2014), The Economic Impact of Modern Retail on Choice and Innovation in the EU Food Sector, European Union, Luxembourg, ISBN 978-92-79-40324-8, doi: 10.2763/77405, pp. 1-452, available at: http://ec.europa.eu/competition/publications/KD0214955ENN.pdf (accessed 24 July 2019).

Fenyves, V. (2016), "Analysis of financial statements of enterprises engaged in food retailing activities in the Northern Great Plain Region", Habilitation Dissertation, University of Debrecen Habilitation Booklets, Habilitation Committee of Social Sciences, Faculty of Economics, Debrecen.

Fenyves, V. and Zsidó, K.E. (2014), "Analysis of liquidity risk among a Hungarian and a Romanian region's enterprises", Forum on Economics and Business, Vol. 18 No. 118, pp. 34-56.

Gandhi, G. and Srivastava, R. (2014), "Analysis and implementation of modified K-Medoids algorithm to increase scalability and efficiency for large dataset", IJRET: International Journal of Research in Engineering and Technology, Vol. 03 No. 150, pp. 150-153, eISSN: 23191163, pISSN: 2321-7308.

Györe, D., Juhász, A., Kartali, J., Kőnig, G., Kürthy, G., Kürti, A. and Stauder, M. (2009), The Structure of the Domestic Food Retail, with Special Regard to the Possibilities of Small Producers, Agricultural Research Institute, AKI, Budapest, Vol. 2, HU ISSN 1418 2122, ISBN 978963491 5324.

Hernant, M., Andersson, T.B. and Hilmola, O.P. (2007), "Managing retail chain profitability based on local competitive conditions: preliminary analysis", International Journal of Retail \& Distribution Management, Vol. 35 No. 11, pp. 912-935, doi: 10.1108/09590550710828236.

Hitt, M., Tihanyi, L., Miller, T. and Connelly, B. (2006, "International diversification: antecedents, outcomes, and moderators", Journal of Management, Vol. 32 No. 6, pp. 831-867, doi: 10.1177/ 0149206306293575.

McCullough, E.B., Pingali, P.L. and Stamoulis, K.G. (2008), The Transformation of Agri-Food Systems: Globalization, Supply Chains and Smallholder Farmers, The Food and Agriculture Organization of the United Nations and Earthscan, London.

Miles, S. (2012), "Stakeholder: essentially contested or just confused?", Journal of Business Ethics, Vol. 108 No. 3, pp. 285-298.

Musinszki, Z. (2013), "What does the balance show? Fundamentals of quotient analysis and pitfalls", Part I, Controller Info, Vol. 1 No. 12, pp. 20-26.

Musinszki, Z. (2014), "Cost, to be a cost? Cost in the management accounting”, Controller Info Studies, Copy \& Consulting and Unio Publishing, pp. 134-138, ISBN 9978-963-08-9751-8.

Myers, H. and Alexander, N. (1997), "Food retailing opportunities in Eastern Europe", European Business Review, Vol. 97 No. 3, pp. 124-133.

Nábrádi, A. and Petö, K. (2009), Different Levels of Performance Indicators, Long Term Experiments in Agriculture, University of Debrecen Research Center, Debrecen, pp. 1-21, ISBN 978-963-473292-1. 
BFJ

122,11

3470

Neely, A., Gregory, M. and Platts, K. (1995), "Performance measurement system design - a literature review and research agenda", International Journal of Operations \& Production Management, Vol. 15 No. 4, pp. 80-116, MCB University Press.

Newman, A.J. and Cullen, P. (2001), "From retail theatre to retail food show. The shrinking face of grocery", British Food Journal, Vol. 103 No. 7, pp. 443-452.

Oh, C.H., Sohl, T. and Rugman, A.M. (2015), "Regional and product diversification and the performance of retail multinationals", Journal of Retailing and Consumer Services, Vol. 21 No. 3, pp. 220-234, doi: 10.1016/j.intman.2015.04.002.

Park, H.S. and Jun, C.H. (2009), “A simple and fast algorithm for K-medoids clustering”, Expert Systems with Applications, Vol. 36 No. 2009, pp. 3336-3341.

Rappaport, A. (1998), Creating Shareholder Value - A Guide for Managers and Investors, 2nd ed., The Free Press, New York.

Ristea, M. (2003), Accounting of the Result of the Enterprise, Economica Publishing House, Bucharest.

Rudawska, E.D. and Bilinska-Reformat, K. (2018), "The development of food retail formats - evidence from Poland”, British Food Journal, Vol. 120 No. 2, pp. 309-324.

Sohl, T. (2012), "Diversification strategies in the global retailing industry: essays on the dimensions and performance implications", Doctoral dissertation, University of St. Gallen, School of Management, Economics, Law, Social Sciences, and International Affairs, Sankt-Gallen.

Sajtos, L. and Mitev, A. (2007), SPSS Manual for Research and Data Analysis, Alinea Publisher, Budapest.

Sandhya, H. and Surya, P.V. (2015), "K-medoid clustering for heterogeneous data sets, 4th International Conference on Eco-friendly Computing and Communication Systems (ICECCS)", Procedia Computer Science, Vol. 70 No. 2015, pp. 226-237.

Soni, K.G. and Patel, A. (2017), "Comparative analysis of K-means and K-medoids algorithm on IRIS data", International Journal of Computational Intelligence Research, Vol. 13 No. 5, pp. 899-906.

Szücs, I. and Farkasné, F.M. (2008), Efficiency in Agriculture (Theory and Practice), Agroinform Publisher, Budapest.

Takacs, A. (2014), "The relationship between appraised company values and future stock prices in the international banking sector", International Research Journal of Finance and Economics, No. 118, pp. 113-123.

Takacs, A. (2015), "The explanatory power of appraised brand values on stock prices in the financial services sector", International Journal of Business Excellence, Vol. 8 No. 3, pp. 298-311.

Tangen, S. (2005), "Demystifying productivity and performance”, International Journal of Productivity and Performance Management, Vol. 54 No. 1, pp. 34-46.

Tibshirani, R., Walther, G. and Hastie, T. (2001), "Estimating the number of data clusters via the Gap statistic", Journal of the Royal Statistical Society B, Vol. 63 No. 2, pp. 411-423.

Tompa, T. (2017), Cluster Analysis, University of Miskolc, Faculty of Mechanical Engineering and Informatics, Miskolc, available at: https://users.iit.uni-miskolc.hu/ tompa/KorszeruInfTech/2_ CA.pdf, (accessed 20 July 2018).

Velmurugan, T. and Santhanam, T. (2010), "Computational complexity between K-means and Kmedoids clustering algorithms for normal and uniform distributions of data points", Journal of Computer Science, Vol. 6 No. 3, pp. 363-368.

Velmurugan, T. (2012), "Efficiency of k-means and K-medoids algorithms for clustering arbitrary data points", International Journal of Computer Technology \& Applications, Vol. 3 No. 5, pp. 1758-1764.

Wimmer, Á. (2000), Corporate Performance Measurement for Value Creation, Budapest University of Economics and Public Administration, Budapest. 
Zéman, Z., Gábor, A. and Bárczi, J. (2018), "The importance of controlling in sustainable development the role of the information support of strategic management, Company diagnostics, controlling and logistics", 9th International Scientific Conference (Proceedings), Zilina, Slovakia, EDIS Zilina University Publishers, pp. 294-302.

Retail food small businesses

Zsido, K. and Stefanescu, D. (2017), "Sustainability and performance in trade sector", The Contemporary Economy Review, Vol. 2 No. 3, pp. 228-238.

Zsido, K.E. (2018), "The characteristics of today's (international and Romanian) food retail trade", Studia Universitatis Petru Maior, Series Oeconomica, pp. 131-152, ISSN -L 1843-1127, ISSN 2286-3249 (ONLINE), ISSN 2286-3230 (CD-ROM).

\section{Corresponding author}

Kinga Emese Zsido can be contacted at: kinga.zsido@umfst.ro

For instructions on how to order reprints of this article, please visit our website:

www.emeraldgrouppublishing.com/licensing/reprints.htm

Or contact us for further details: permissions@emeraldinsight.com 